\title{
Continuing trophic cascade effects after 25 years of no-take marine reserve protection
}

\author{
Nick T. Shears* ${ }^{*}$ Russell C. Babcock \\ Leigh Marine Laboratory, University of Auckland, PO Box 349, Warkworth, New Zealand
}

\begin{abstract}
Between 1978 and 1996 benthic communities in the Leigh Marine Reserve shifted from being dominated by sea urchins to being dominated by macroalgae. This was a result of a trophic cascade thought to be an indirect effect of increased predator abundance. We assessed further changes in communities from 1996 to 2000, differences in benthic communities between reserve and adjacent unprotected sites, and the stability of these patterns from 1999 to 2001. Since 1996, densities of sea urchins Evechinus chloroticus have continued to decline in shallow areas of the reserve $(<8 \mathrm{~m})$, and all sites classified as urchin barrens in 1978 are now dominated by large brown algae. Comparisons between reserve and non-reserve sites revealed differences consistent with a trophic cascade at reserve sites. The greatest differences in algal communities between reserve and non-reserve sites occurred at depths where E. chloroticus was most abundant (4 to $6 \mathrm{~m}$ ). Reserve sites had lower urchin densities and reduced extent of urchin barrens habitat with higher biomass of the 2 dominant algal species (Ecklonia radiata and Carpophyllum maschalocarpum). At reserve sites densities of exposed E. chloroticus (openly grazing the substratum) declined so that urchin barrens were completely absent by 2001. Lower density of the limpet Cellana stellifera and higher densities of the turbinid gastropod Cookia sulcata at reserve sites are thought to be responses to changes in habitat structure, representing additional indirect effects of increased predators. The overall difference in community types between reserve and non-reserve sites remained stable between 1999 and 2001. Localised urchin mortality events due to an unknown agent were recorded at some sites adjacent to the marine reserve. Only at 1 of these sites did exposed urchins decline below the critical density of $1 \mathrm{~m}^{-2}$, which resulted in the total replacement of urchin barrens with macroalgae-dominated habitats. At other sites urchin barrens have remained stable. Declines in the limpet $C$. stellifera occurred across all sites between 1999 and 2001 and may be indirectly associated with urchin declines. Long-term changes in benthic communities in the Leigh reserve and the stability of differences between reserve and nonreserve sites over time are consistent with gradual declines in urchin densities due to increased predation on urchins, thus providing further evidence for a trophic cascade in this system. The rapid declines in urchin numbers at some unprotected sites, however, demonstrate how short-term disturbances, such as disease, may result in shifts in community types over much shorter time frames.
\end{abstract}

KEY WORDS: Benthic community structure $\cdot$ Macroalgae $\cdot$ Macro-invertebrate herbivores $\cdot$ Marine protected areas $\cdot$ Northeastern New Zealand $\cdot$ Sea urchins $\cdot$ Temporal change

Resale or republication not permitted without written consent of the publisher

\section{INTRODUCTION}

Trophic cascades represent a series of interactions whereby plant community structure or 'biomass of primary producers' is indirectly controlled by the presence of top predators (Hairston et al. 1960, Menge 1995). When predators do not suppress herbivores, grazing reduces plant biomass. The occurrence of both trophic cascades and the potential for human-induced alterations to trophic cascades are becoming more apparent (Pace et al. 1999, Polis et al. 2000). Trophic cascades are characterised by 3 features: (1) top-down control of assemblage structure by predators; (2) conspicuous indirect effects, with 2 or more links distant from the primary one; and (3) persistence of alternative community states. While trophic cascades in the marine environ- 
ment have received much attention, and their potential is indicated by theoretical studies, there are few empirical studies, with one of the main limitations being the lack of long-term data (Pinnegar et al. 2000).

Fishing is the most widespread human impact on the marine environment (Pauly et al. 1998, Jackson et al. 2001). Fishing not only has direct effects on target populations but also results in indirect effects throughout the ecosystem when top-level predators are removed (see reviews by Jennings \& Kaiser 1998, Pinnegar et al. 2000, Tegner \& Dayton 2000). On many temperate reefs shifts from macroalgae-dominated habitats to habitats grazed by sea urchins, termed 'urchin barrens', have been linked to the over-harvesting of top predators, e.g. Alaska (Estes \& Duggins 1995), Northwest Atlantic (Wharton \& Mann 1981, Vadas \& Steneck 1995), New Zealand (Babcock et al. 1999, Shears \& Babcock 2002) and the Mediterranean (Sala et al. 1998). Despite the widespread occurrence of apparent trophic cascades, evidence for a key role of predators is mostly circumstantial (Scheibling 1996), and little is known about the stability of the alternate stable states and the processes leading to their establishment.

Grazing by high densities of sea urchins results in the transition from kelp forests to urchin barrens (Lawrence 1975). Therefore, understanding the factors regulating sea urchin abundance is pivotal to understanding the mechanisms responsible for this shift in community type. Reversals of this shift (from urchin barrens back to kelp) have been linked to not only the recovery of predators (e.g. sea otters, Estes \& Duggins 1995), but also to high algal recruitment (Harrold \& Reed 1985) and mass mortality of urchins due to storms (Ebeling et al. 1985) and disease (Scheibling \& Hennigar 1997). Similarly, harvesting of sea urchins results in the reestablishment of macroalgal forests (Steneck 1997). In systems where harvesting occurs at many trophic levels, e.g. Californian kelp forests (Dayton et al. 1998), many trophic interactions have been lost, and consequently our ability to understand the processes responsible for the establishment and stability of algal assemblages is severely compromised.

Marine reserves, or other areas where fishing is completely prohibited, are therefore a valuable tool in understanding the persistence and stability of communities. Such areas provide an ecosystem-level experimental framework to detect both the direct and indirect effects of fishing, which may not be detectable using small-scale manipulations (Shears \& Babcock 2002, cf. Andrew \& Choat 1982). Furthermore, monitoring marine reserves and adjacent unprotected areas over long periods allows the differentiation of fishing effects from long-term changes associated with other factors such as natural disturbance and climate change. If predators have an important regulatory effect on sea urchins, we would expect a transition from urchin barrens back to kelp after a period of predator recovery. Not all studies on temperate reefs that have utilised marine reserves to address such questions have found strong evidence for trophic cascades (Edgar \& Barrett 1997, 1999, Cole \& Keuskamp 1998, Sala et al. 1998). This may be due to a number of reasons, including inherent aspects of the particular system examined, studies being carried out over insufficient periods of time and also a lack of long-term data.

Long-term studies at permanent sites in New Zealand's oldest marine reserve, the Cape Rodney to Okakari Point Marine Reserve (hereafter 'Leigh Reserve'; established in 1976), have revealed a transition from urchin barrens to kelp after 20 yr of marine reserve protection (Babcock et al. 1999). On moderately exposed reefs in this part of northeastern New Zealand the urchin barrens habitat typically occurs at depths between 3 and $8 \mathrm{~m}$ (Choat \& Schiel 1982, Shears \& Babcock 2000) and is maintained by the grazing activity of the sea urchin Evechinus chloroticus (Andrew \& Choat 1982, Shears \& Babcock 2002) along with a group of herbivorous gastropod species (Ayling 1981, Choat \& Andrew 1986). Urchin numbers in the Leigh Reserve have declined, and there has been a subsequent 10 -fold decline in the extent of urchin barrens habitat from $31.4 \%$ of available reef in 1978 to $3.2 \%$ in 1996 (Babcock et al. 1999). In addition, both the density of E. chloroticus and the extent of the urchin barrens habitat is significantly lower in the Leigh Reserve, and also in the nearby Tawharanui Marine Park, compared with adjacent unprotected areas (Shears \& Babcock 2002). Both reserves have considerably higher abundances of predators, predominantly the snapper Pagrus auratus (Willis et al. 2000, in press) and the spiny lobster Jasus edwardsii (Kelly et al. 2000) compared with unprotected areas where these species are heavily targeted by both recreational and commercial fishermen. Both snapper and spiny lobsters are the dominant predators of adult E. chloroticus, and the chance of predation on tethered urchins is approximately 7 times higher in these reserves than on the adjacent coast (Shears \& Babcock 2002). Consequently, the long-term declines in urchin barrens in the Leigh Reserve and the spatially consistent contrasts between these fished and un-fished areas have been attributed to a top-down role of predators (Babcock et al. 1999, Shears \& Babcock 2002).

While these patterns provide strong evidence for a trophic cascade in this system, no temporal data exist for non-reserve sites, and many inferences concerning the effects of reserves are based on one-off comparisons of reserve and non-reserve sites. Furthermore, little is known about the stability of the observed changes and the processes that lead to transitions from one habitat 
state to the next. If such a trophic cascade exists in this system, we make the following predictions based on the 3 characteristics of trophic cascades described above: (1) Habitat change in the reserve will continue towards kelp domination given the persistence of top-down control on assemblage structure. (2) Indirect effects 2 or more steps away from the primary one will be apparent, e.g. potential effects on algae and also other grazers associated with declines in Evechinus chloroticus. (3) Alternative stable states will persist through time between reserve and non-reserve sites. These hypotheses were tested by extending time-series data from permanent sites within the reserve first measured between 1976 and 1978 (Ayling 1978), from 1996 (Babcock et al. 1999) to 2000. In addition, benthic communities at a number of reserve and non-reserve sites were monitored from 1999 to 2001. Since the abundance of the dominant urchin predators has remained considerably higher at reserve sites compared to unprotected areas, the habitat change should remain stable or continue its trend towards a kelp-dominated state. Alternatively, if the spatial contrasts in habitat structure since 1978 were related to some chance temporal variation, we should expect to see considerable variation in habitat structure between 1994 and 2000, in which time the reserve has been more intensively monitored. If spatial differences in habitat structure between reserve and non-reserve sites are a result of trophic interactions, they are predicted to be stable over time. However, if habitat structure changes towards a kelp-dominated system outside the reserve, other processes may be responsible for such transitions.

\section{METHODS}

Study area. The Leigh Reserve is located approximately $90 \mathrm{~km}$ north of Auckland on the east coast of New Zealand's North Island (Fig. 1). The nearshore areas within the reserve and along the adjacent coasts contain areas of contiguous reef extending from mean low water spring (MLWS) to depths generally greater than $10 \mathrm{~m}$. Reef communities in the Leigh area have previously been described (Bergquist 1960, Choat \& Schiel 1982, Taylor 1998, Shears \& Babcock 2000). See Table 1 for a description of habitats.

Temporal change at permanent sites. Thirteen $100 \mathrm{~m}^{2}$ 'permanent sites', established by Ayling (1978), were re-sampled during 20-24 September 1999 and 3-9 August 2000. These were grouped among 3 depth strata: shallow $(<5 \mathrm{~m} ; \mathrm{n}=4)$, mid-depth $(6$ to $8 \mathrm{~m} ; \mathrm{n}=5)$ and deep (10 to $\left.13 m_{i} n=4\right)$. Most of the permanent sites were located in Goat Island Bay (Fig. 1), although a shallow and a mid-depth site were located at Waterfall Reef in the eastern part of the reserve. In 1978, shallow sites were classified as 'shallow broken rock/ rockflats', mid-depth sites as 'rock flats' and deep sites as 'kelp forest' (Table 1; Ayling 1978).

The positions of Ayling's sites were located using compass bearings and distances from prominent landmarks as in Babcock et al. (1999). Each site was sampled using 10 haphazardly placed $1 \mathrm{~m}^{2}$ quadrats. All large brown macroalgae and invertebrate herbivores were counted and measured. The density and size structure of dominant species were compared with data from 1994, 1996 (Babcock et al. 1999), and the original 1976-78 data (Ayling 1978).

Spatial contrasts and temporal change at reserve and non-reserve sites. Site selection and locations: Eight sites were sampled throughout the Leigh Reserve and along the adjacent coastline (Fig. 1). All sites had moderately sloping reefs and similar topographic complexity. GPS co-ordinates were recorded at each site, along with a photograph of the intertidal rock formations, allowing exact relocation of the sites. Sampling was carried out during late summer 1999 (12 to $29 \mathrm{March}$ ), 2000 (5 to 15 April) and 2001 (27 March to 10 April). It is unlikely that the seasonal variation in sampling time (both among these samples and relative to the 'permanent' sites of Ayling 1978) will introduce a significant source of variation in algal communities. Previous
Fig. 1. Location of Cape Rodney to Okakari Point Marine reserve in northeastern New Zealand. Names indicate study sites where subtidal communities were monitored from 1999 to 2001. Dashed line indicates reserve boundary 
Table 1. Description of benthic habitats encountered in this study

\begin{tabular}{|c|c|c|}
\hline Habitat & $\begin{array}{l}\text { Depth range } \\
(\mathrm{m})\end{array}$ & Description \\
\hline Shallow Carpophyllum ${ }^{\mathrm{a}}$ & $<3$ & $\begin{array}{l}\text { Dominated by high abundances }\left(\geq 20 \mathrm{~m}^{-2}\right) \text { of Carpophyllum maschalocarpum, } \\
\text { C. plumosum and C. angustifolium. Ecklonia radiata, Xiphophora chondrophyl- } \\
\text { la and Pterocladia lucida are also common. Urchins rare and generally cryptic }\end{array}$ \\
\hline Mixed algae $^{a}$ & $2-10$ & $\begin{array}{l}\text { Mixture of short Ecklonia radiata plants and fucalean algae }{ }^{\mathrm{b}} \text { (mainly } C \text {. mascha- } \\
\text { locarpum), usually only partial canopy }\left(\geq 4 \text { adult plants } \mathrm{m}^{-2} \text { ) and urchins may }\right. \\
\text { also be common }\end{array}$ \\
\hline $\begin{array}{l}\text { Urchin barrens } \\
\text { ('rockflats' in Ayling 1978) }\end{array}$ & $2-9$ & $\begin{array}{l}\text { Areas where the grazing activity of Evechinus chloroticus }\left(>2 \text { adults } \mathrm{m}^{-2} \text { ) leaves }\right. \\
\text { the substratum relatively devoid of macroalgae and dominated by crustose } \\
\text { coralline algae. Large brown algae, particularly C. flexuosum, may occur at low } \\
\text { densities }\left(<4 \text { adult plants } \mathrm{m}^{-2}\right)\end{array}$ \\
\hline Turfing algae & $3-9$ & $\begin{array}{l}\text { Substratum predominantly covered by turfing algae (e.g. articulated corallines } \\
\text { [Coralline turf] and short foliose red algae) ( }>30 \% \text { cover). Low numbers of large } \\
\text { brown algae }\left(<4 \text { adult plants } \mathrm{m}^{-2}\right) \text { and urchins may occur }\end{array}$ \\
\hline Kelp forest & $5-20$ & $\begin{array}{l}\text { Generally monospecific stands of mature Ecklonia radiata forming a complete canopy } \\
\left(\geq 4 \text { adult plants } \mathrm{m}^{-2}\right) \text {, occasional C. flexuosum plants. Urchins rare, usually cryptic }\end{array}$ \\
\hline
\end{tabular}

studies have described little if any seasonal variation and the persistence of habitats year round (Novaczek 1980, Ayling 1981, Schiel 1985). Reef communities at each site were sampled to a maximum depth of $12 \mathrm{~m}$ using a combination of line transects and depth-stratified quadrats. This provided information on the distribution of habitats along the depth gradient as well as a quantitative measure of abundance of benthic communities within 4 given depth ranges.

Line transects: Three line transects were haphazardly placed at each site to identify the depth distribution of habitats and to obtain information on the reef profile at each site. Transects were run perpendicular to the shore on a fixed compass bearing from MLWS (or the top of Carpophyllum maschalocarpum band) to the edge of the reef, or a maximum of $12 \mathrm{~m}$ depth, whichever was encountered first. The habitat type (Table 1), depth, rock type, slope and distance from shore were recorded at $5 \mathrm{~m}$ intervals along these transects. The habitat classification used was similar to that used by Ayling (1978) but with an additional 'mixed algal' habitat, typically characterised by a mixture of Ecklonia radiata and C. maschalocarpum (see Shears \& Babcock 2000).

Transect data were analysed as the proportion of major habitat types at each site. Proportions were calculated as the distance covered by each habitat type from the start of the transect (MLWS) to a depth of $10 \mathrm{~m}$, divided by the transect length. The cut-off depth of $10 \mathrm{~m}$ was chosen because urchin barrens rarely occur below this depth around Leigh, and the reefs are completely dominated by kelp forest (Shears \& Babcock 2002). The proportions of each of the major habi- tat types were analysed using a generalised linear mixed model with fixed factors Year (1999, 2000 and 2001) and Status (Reserve and Non-reserve). Covariance parameter estimates were calculated for the random factor Site (Year $\times$ Status) and also for the auto-regressive error structure $(\mathrm{AR}(1))$ to account for repeated measures. The proportion data were modelled using a binomial distribution, and the model was back-fitted using residual (restricted) maximum likelihood employing the GLMMIX macro in SAS (Littell et al. 1996). The parameter estimates from the model were used to calculate the relative odds ratio, or chances of habitats occurring at reserve versus nonreserve sites, along with 95\% confidence limits (see Willis \& Millar [2001] for explanation of interpreting relative odds). Note that confidence limits are asymmetrical as they are calculated on the log-scale.

Depth-stratified quadrats: At each site, 5 haphazardly placed $1 \mathrm{~m}^{-2}$ quadrats were sampled in each of 4 depth ranges $(<2,4$ to 6,7 to 9 and $>10 \mathrm{~m}$ below MLWS) to provide information on abundance and size structure of dominant organisms. Depths were corrected according to the state of the tide to ensure accurate positioning of quadrats within the desired depth range. It was important that specific narrow depth ranges were selected to ensure comparable repeated sampling. The depth ranges chosen also ensured that sampling was carried out within specific zones previously described at Leigh, shallow Carpophyllum maschalocarpum (<2 m), urchin barrens (4 to $6 \mathrm{~m}$ ) and kelp forest ( 7 to 9 and $>10 \mathrm{~m}$ ) (Choat \& Schiel 1982, Shears \& Babcock 2000). Quadrats were positioned haphazardly adjacent to the transect line in the desired 
depth range, and the distance along the transect recorded to ensure that subsequent sampling could be carried out in the same general area.

Within each quadrat all macroalgae and macroinvertebrate herbivores were counted. The test diameter of all urchins ( $>5 \mathrm{~mm}$ ) was measured to the nearest $5 \mathrm{~mm}$ as well as whether each urchin occupied a crevice (cryptic) or openly grazed the substratum (exposed). The total lengths of individual thalli of large brown macroalgae were measured $( \pm 5 \mathrm{~cm})$, as it is difficult to differentiate individual plants for many species. Additional measures of stipe length were made for Ecklonia radiata. The percent cover of encrusting, turfing and foliose forms of algae was estimated (turfing algae were defined as mat forming species generally less than $5 \mathrm{~cm}$ height). Algal measurements were converted to biomass for statistical analysis, using lengthweight and percent cover-weight relationships (Table 2). To obtain length-weight relationships a number of plants covering a range of sizes were measured to the nearest $\mathrm{cm}$, dried at $80^{\circ} \mathrm{C}$ and weighed to the nearest $0.1 \mathrm{~g}$. For functional groups, which generally only made a small contribution to overall algal biomass, percent cover estimates were converted to dry weight. These were calculated from three $10 \times 10 \mathrm{~cm}$ $\left(0.01 \mathrm{~m}^{2}=1 \%\right)$ samples that were collected, dried and weighed.

Overall differences in algal communities between years and between reserve and non-reserve sites were tested using non-parametric multivariate analysis of variance (NP-MANOVA) (Anderson 2001). Ecological data very rarely conform to the strict normality assumptions of traditional parametric MANOVA, so non-parametric techniques based on permutation tests are preferred. Analysis was carried out on biomass data for the 12 mostdominant species, while the remaining species were grouped into 11 functional groups (Table 2). The analysis was based on BrayCurtis similarities, and data were fourth-root transformed to ensure that all species or groups, abundant or rare, contributed to the triangular matrix (Clarke \& Warwick 1994). NP-MANOVA cur- rently does not allow 3-way tests, so separate analyses on the effect of Year and Status, with Site as a nested term, were carried out for each of the 4 depth ranges. No corrections were made to adjust for multiple testing; however, permutation tests calculate exact p-values. Non-metric multidimensional scaling (MDS) was used to display similarities in overall algal communities between sites and years and similarity percentages analysis (SIMPER) was used to identify the species responsible for differences between reserve and nonreserve sites (Clarke \& Warwick 1994).

Differences in the abundance of urchins, herbivorous gastropods and the biomass of the 2 dominant macroalgal species (Ecklonia radiata and Carpophyllum maschalocarpum) were compared between reserve and non-reserve sites and between years using a generalised linear mixed model. The factors Year, Status and Depth range were treated as fixed factors and Site (Year $\times$ Status) as a random effect. The model was fit-

Table 2. Algal species and functional groups used in analysis along with length-weight and/or percent cover-weight relationships for biomass estimates. $y=$ dry weight ( $g$ ), $x=$ total length $(\mathrm{cm}), \mathrm{SL}=$ stipe length $(\mathrm{cm})$ and $\mathrm{LL}=$ laminae length $(\mathrm{cm})$

\begin{tabular}{|c|c|c|c|}
\hline Species & Equation & $\mathrm{R}^{2}$ & $\mathrm{n}$ \\
\hline \multicolumn{4}{|l|}{ Brown algae } \\
\hline Carpophyllum angustifolium ${ }^{\mathrm{a}}$ & $y=0.068 x-0.27$ & 0.92 & 23 \\
\hline C. maschalocarpum & $\ln (y)=1.764 \ln (x)-4.311$ & 0.72 & 46 \\
\hline C. plumosum & $\ln (y)=1.472 \ln (x)-3.850$ & 0.66 & 62 \\
\hline C. flexuosum & $\ln (y)=2.049 \ln (x)-5.251$ & 0.90 & 52 \\
\hline Xiphophora chondrophylla & $y=1.786 x-4.171$ & 0.62 & 18 \\
\hline \multirow{2}{*}{$\begin{aligned} \text { Ecklonia radiata }^{\mathrm{a}} & - \text { Stipe } \\
& \text { - Laminae }\end{aligned}$} & $\ln (y)=1.671 \ln (\mathrm{SL})-3.787$ & 0.97 & 46 \\
\hline & $\ln (y)=1.177 \ln (\mathrm{SL} \times \mathrm{LL})-3.879$ & 0.94 & 55 \\
\hline Sargassum sinclairii & $y=0.075 x+0.124$ & 0.58 & 25 \\
\hline Landsburgia quercifolia & $\ln (y)=1.971 \ln (x)-5.058$ & 0.83 & 19 \\
\hline Small brown algae, & $\ln (y)=2.587 \ln (x)-6.443$ & & \\
\hline e.g. Zonaria turneriana & $1 \%=2.5 \mathrm{~g}$ & 0.83 & 27 \\
\hline Brown turf, e.g. Distromium, Dictyota spp. & $1 \%=1.5 \mathrm{~g}$ & & \\
\hline Brown encrusting, e.g. Ralfsia & $1 \%=0.1 \mathrm{~g}$ & & \\
\hline \multicolumn{4}{|l|}{ Red algae } \\
\hline Osmundaria colensoi & $\begin{array}{l}\ln (y)=1.720 \ln (x)-3.379 \\
1 \%=22.9 g\end{array}$ & 0.70 & 14 \\
\hline Pterocladia lucida & $\begin{array}{l}\ln (y)=1.963 \ln (x)-5.076 \\
1 \%=10.0 \mathrm{~g}\end{array}$ & 0.73 & 47 \\
\hline Melanthalia abscissa & $\ln (y)=1.775 \ln (x)-4.247$ & 0.64 & 22 \\
\hline Red foliose, e.g. Plocamium spp. & $\ln (y)=2.649 \ln (x)-8.812$ & 0.80 & 34 \\
\hline Red turfing $(<5 \mathrm{~cm})$, e.g. Champia spp. & $1 \%=1.7 \mathrm{~g}$ & & \\
\hline Coralline turf ${ }^{\text {b }}$, e.g. Corallina officinalis & $1 \%=4.5 \mathrm{~g}$ & & \\
\hline Crustose corallines & $1 \%=0.1 \mathrm{~g}$ & & \\
\hline Red encrusting & $1 \%=0.1 \mathrm{~g}$ & & \\
\hline \multicolumn{4}{|l|}{ Green algae } \\
\hline Codium convolutum & $1 \%=4.7 \mathrm{~g}$ & & \\
\hline Others, e.g. Ulva sp. & $1 \%=1.7 \mathrm{~g}$ & & \\
\hline Filamentous algae & $1 \%=0.2 \mathrm{~g}$ & & \\
\hline \multicolumn{4}{|c|}{${ }^{\mathrm{a}}$ From Choat \& Schiel (1982) } \\
\hline \multicolumn{4}{|c|}{$\begin{array}{l}{ }^{\mathrm{b}} \text { The proportion of } \mathrm{CaCO}_{3} \text { in Corallina officinalis has been estimated as } 45 \% \text { of the dry } \\
\text { weight (M. Taylor unpubl. data). The value given is the total dry-weight of samples less } \\
45 \%\end{array}$} \\
\hline
\end{tabular}


ted using the same procedure as for the habitat data (previous section) but to a Poisson distribution. Ratios of density or biomass between levels of significant fixed factors were calculated to provide an estimate of the size of main effects.

\section{RESULTS}

\section{8 to 2000: Long-term changes at permanent sites}

The greatest changes since 1978 have occurred at permanent sites located in the mid-depths (Fig. 2). These sites, originally classified as urchin barrens (Ayling 1978), are now dominated by Ecklonia radiata, and urchins are rare. At shallow sites, urchin densities have generally been variable since 1978 (Fig. 2), although the density of E. radiata and fucalean algae have increased in recent years. The deeper sites (Fig. 2), which are dominated by mono-specific stands of $E$. radiata, have remained relatively stable over time. Low densities of E. radiata in 1994 resulted from a large-scale dieback which occurred in 1993 (Cole \& Babcock 1996). The relatively high densities in 1978 are attributable to a large number of recruits (Ayling 1978), and the densities of adults are comparable to those today.

In general, trends in habitat change between 1978 and 1994 have continued since 1996 at all permanent sites, but this change has not been simultaneous at all sites. Prior to this study the mid-depth site at Waterfall Reef remained as urchin barrens, but in 2000 there was a considerable increase in both Ecklonia radiata and fucaleans (Fig. 3). Urchin populations at this site were dominated by adults (>50 mm TD) in 1978, 1994 and 1996 (Fig. 3), and both Carpophyllum maschalocarpum and E. radiata were rare. In 1999 and 2000 the number of adult urchins were declining and cryptic juveniles dominated the populations, allowing successful recruitment of $C$. maschalocarpum and $E$. radiata (Fig. 3).

\section{9 to 2001: Spatial contrasts and temporal change at reserve and non-reserve sites}

\section{Habitat distributions}

Large differences were found in the extent of major habitat types between reserve and non-reserve sites in the shallow subtidal (<10 m depth) (Fig. 4). Most notable was the dominance of urchin barrens at nonreserve sites and the decline of urchin barrens from $4.9 \pm 2.5 \%$ to complete loss of this habitat at all reserve sites between 1999 and 2001. Prior to 2001 urchin bar- rens occurred at low levels at sites in the western part of the reserve (Waterfall and Onespot). The complete absence of urchin barrens in reserve sites in 2001 rendered statistical analysis pointless. At non-reserve sites there was no overall difference among years in the extent of urchin barrens $\left(F_{2,21}=1.52, \mathrm{p}=0.24\right)$. However, at Rodney South urchin barrens declined from $42.1 \pm 0.4$ and $49.7 \pm 6.2 \%$ in 1999 and 2000, respectively, to being completely absent in 2001. This corresponded to an increase in turfing algae, mixed algae and kelp forest at this site.

The reefs at reserve sites had significantly higher cover of mixed algae $\left(F_{1,20}=11.71, \mathrm{p}<0.01\right)$ and kelp forest $\left(F_{1,20}=42.68, \mathrm{p}<0.01\right)$ than those at non-reserve sites (Fig. 4). The likelihood of mixed algae occurring at reserve sites was $3.6\left(\mathrm{CL}_{95}=1.1,6.1\right.$ - upper and lower confidence limits) times higher than at nonreserve sites, while kelp forest was $2.7\left(\mathrm{CL}_{95}=2.0,3.7\right)$ times more likely to occur in the reserve. These

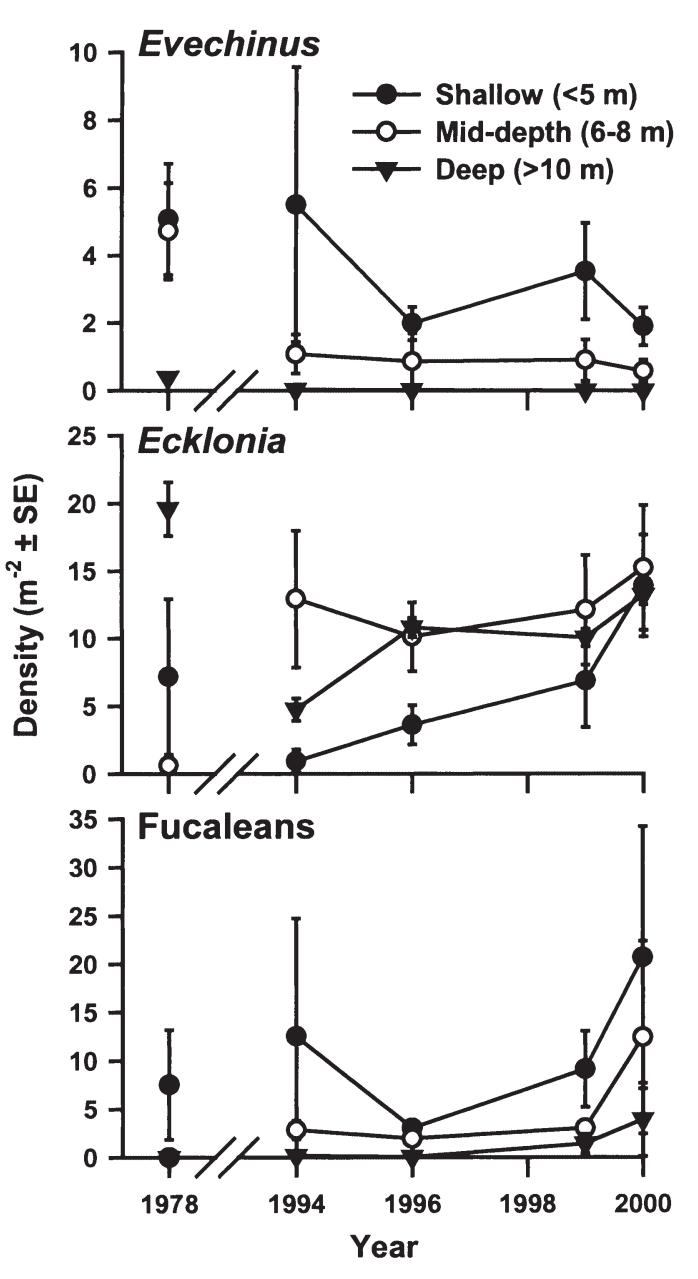

Fig. 2. Changes in Evechinus chloroticus, Ecklonia radiata and fucalean density at permanent sites located in the Leigh Reserve between 1978 and 2001 
E. chloroticus
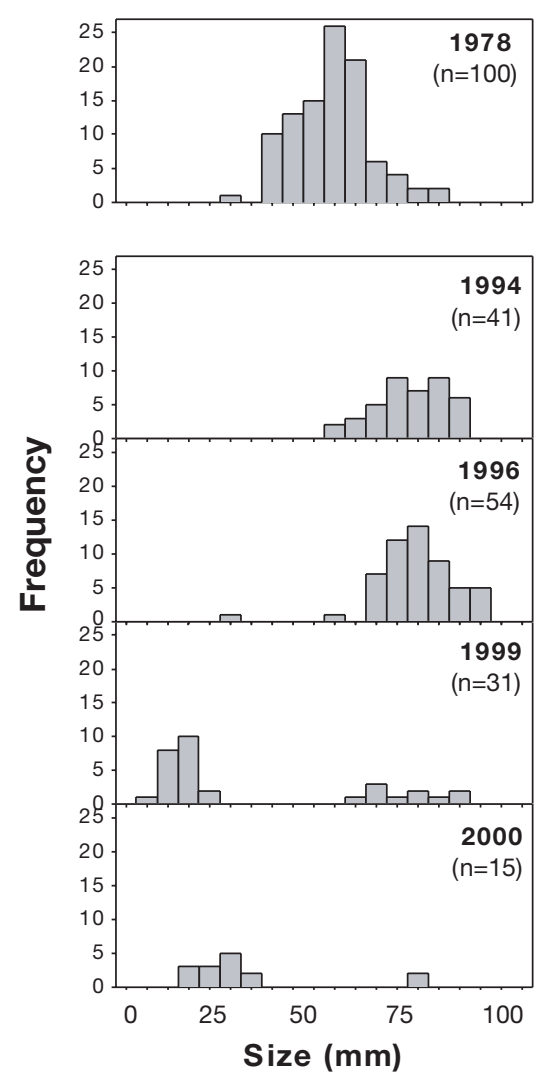

C. maschalocarpum
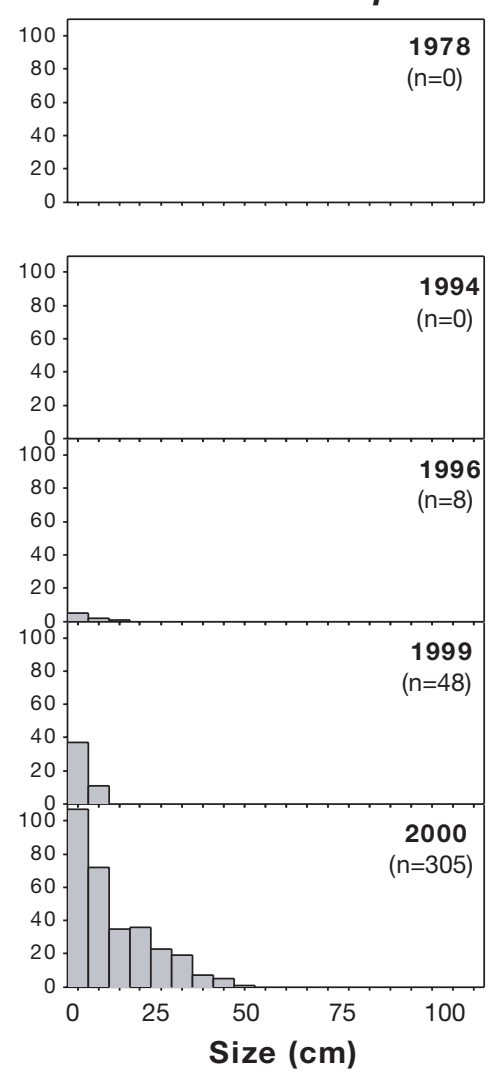

E. radiata
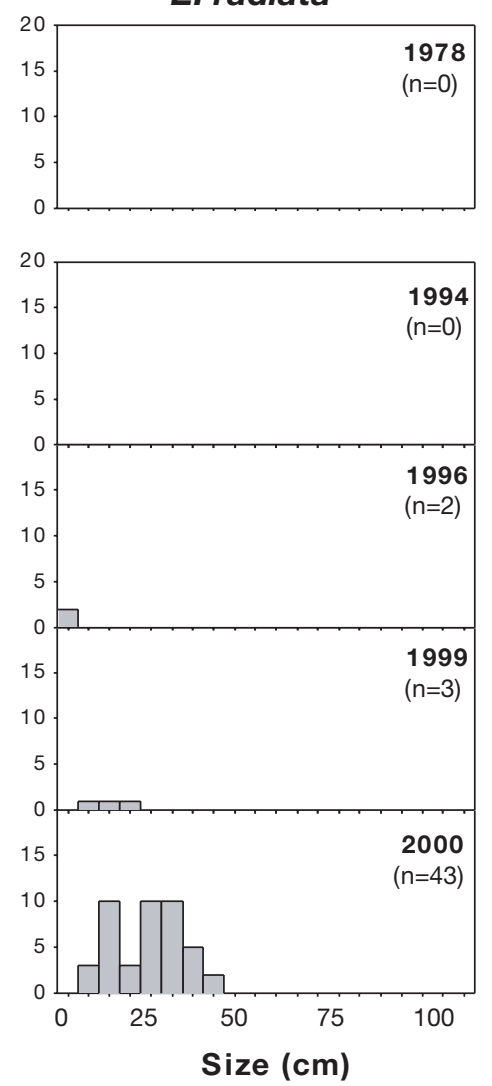

Fig. 3. Changes in Evechinus chloroticus, Carpophyllum maschalocarpum and Ecklonia radiata size-frequency distributions at the Waterfall Reef (mid-depth) permanent site between 1978 and 2001

reserve-related patterns were consistent among years, and there was no overall difference among years in the extent of either mixed algae $\left(F_{2,20}=0.16, \mathrm{p}=0.85\right)$ or $\operatorname{kelp}\left(F_{2,20}=1.94, \mathrm{p}=0.17\right)$.

The cover of shallow Carpophyllum maschalocarpum habitat and turfing algae (Fig. 4) did not differ between reserve and non-reserve sites $\left(F_{1,20}=1.3\right.$, $\mathrm{p}=0.27$ and $\left.F_{1,20}=0.46, \mathrm{p}=0.50\right)$ or between years $\left(F_{2,20}=0.77, \mathrm{p}=0.48\right.$ and $F_{2,20}=2.07, \mathrm{p}=0.15$, respectively). However, there was an apparent increase in turfing algae at non-reserve sites between 2000 and 2001 (Fig. 4).

\section{Invertebrate herbivores}

The density of urchins varied significantly with depth (Fig. 5, Table 3) with most urchins being concentrated in the 4 to $6 \mathrm{~m}$ depth stratum. Densities were $1.7\left(\mathrm{CL}_{95}=1.0,2.9\right)$ and $2.9\left(\mathrm{CL}_{95}=1.7,4.8\right)$ times higher in the 2 shallow depth ranges ( 0 to 2 and 4 to $6 \mathrm{~m}$ ) compared to the 7 to $9 \mathrm{~m}$ depth range. Urchins occurred in very low numbers in the deepest depth stratum (>10 m), so this depth was not included in analyses. Non-reserve sites had $1.84\left(\mathrm{CL}_{95}=1.18,2.87\right)$ times higher densities than reserve sites. There was no difference in overall urchin densities between years.

Urchins exhibiting cryptic behaviour also varied significantly with depth and reserve status but not between years (Fig. 5, Table 3). The density of cryptic urchins, predominantly juveniles (Fig. 6), was actually $2.21\left(\mathrm{CL}_{95}=1.32,3.71\right)$ times higher at reserve sites. The density of exposed urchins at reserve sites was low in 1999, and by 2001 they were absent at all depths except the 7 to $9 \mathrm{~m}$ depth stratum (Fig. 5). Exposed Evechinus chloroticus also declined at all non-reserve sites except Kempts Beach over the 3 yr. The greatest decline occurred at Rodney South, where the densities of exposed urchins dropped from $4.8 \pm 1.0 \mathrm{~m}^{-2}$ in 1999 to $2.4 \pm 0.8 \mathrm{~m}^{-2}$ in 2000 , becoming completely absent in 2001. There were clear differences in urchin population size structures with reserve status (Fig. 6). While the contrast in reserve and non-reserve populations was relatively stable between years, a general decline in exposed urchins at reserve and non-reserve sites was apparent. 


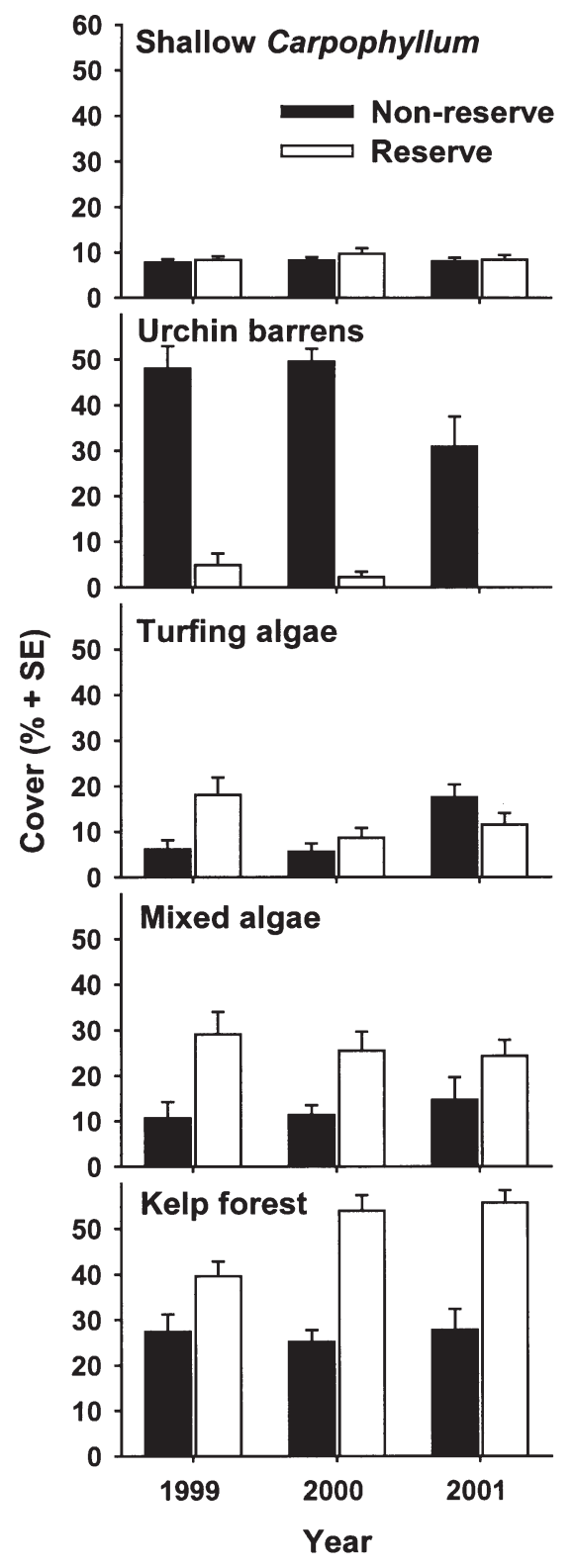

Fig. 4. Extent of major habitat types from line transects $(n=3)$ at reserve and non-reserve sites for 1999 to 2001

The densities of herbivorous gastropod species were generally variable, particularly among depths (Fig. 7, Table 3). Cookia sulcata and Cellana stellifera tended to be more abundant in the 2 shallow depth strata, while Trochus viridis and Cantharidus purpureus occurred at very low densities in the shallow strata and at high densities in the deeper strata. There were widespread declines in both C. sulcata and C. stellifera across all sites between 1999 and 2001. C. sulcata was $2.6\left(\mathrm{CL}_{95}=1.4,4.8\right)$ times more abundant in 1999 than 2001, and C. stellifera $16.9\left(\mathrm{CL}_{95}=4.9,58.3\right)$ times more abundant in 1999. There was also a significant effect of

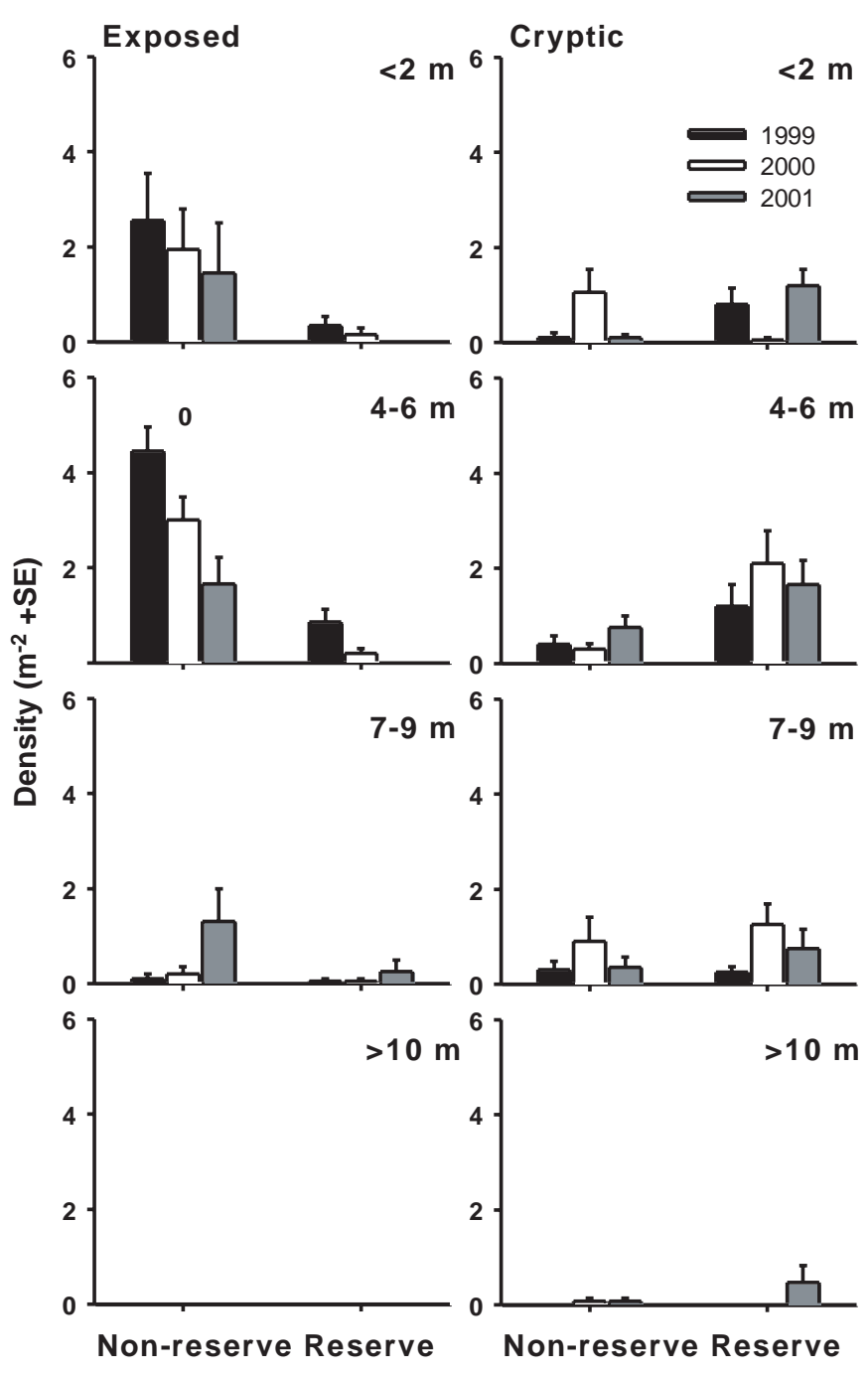

Fig. 5. Density of exposed and cryptic Evechinus chloroticus at reserve and non-reserve sites between 1999 and 2001

reserve status, with $C$. sulcata being $3.0\left(\mathrm{CL}_{95}=1.2\right.$, 7.2) times more abundant at reserve sites, whereas $C$. stellifera was $2.5\left(\mathrm{CL}_{95}=0.9,7.2\right)$ times more abundant at non-reserve sites (Table 3 ).

\section{Macroalgae}

Macroalgal assemblages. There were large differences in algal assemblages between reserve and nonreserve sites (Table 4). These effects differed with depth (Table 5A), and were only significant for the 4 to $6 \mathrm{~m}$ depth range (Fig. 8), where algal biomass was low at non-reserve sites, consistent with high densities of exposed Evechinus chloroticus (Fig. 5). In the 4 to $6 \mathrm{~m}$ depth strata the biomass of Ecklonia radiata, Carpophyllum maschalocarpum, crustose corallines and 
Table 3. Results from mixed model analysis on dominant invertebrate herbivores and algal species from quadrat sampling at reserve and non-reserve sites from 1999 to 2001. Model back-fitted by removing non-significant interaction terms. Analysis excludes depth strata where taxon was absent or very rare. Significance: ${ }^{*} p<0.05,{ }^{* *} p<0.01,{ }^{* * *} p<0.001$

\begin{tabular}{|c|c|c|c|c|c|c|}
\hline & \multirow[b]{2}{*}{ Year } & \multirow[b]{2}{*}{ Status } & \multirow[b]{2}{*}{ Depth range } & \multirow[b]{2}{*}{$\begin{array}{l}\text { Status } \times \text { Depth } \\
\text { range }\end{array}$} & \multicolumn{2}{|c|}{$\begin{array}{c}\text { Covariance parameter } \\
\text { estimates }\end{array}$} \\
\hline & & & & & $\begin{array}{c}\text { Site } \\
(\text { Status } \times \text { Year })\end{array}$ & AR (1) \\
\hline \multicolumn{7}{|l|}{ Evechinus chloroticus } \\
\hline All (excl. >10 m) & $F_{2,20}=0.26$ & $F_{1,20}=7.11^{*}$ & $F_{2,334}=8.95^{* * *}$ & - & 0.04 & $0.16^{*}$ \\
\hline Cryptic (excl. >10 m) & $F_{2,20}=1.82$ & $F_{1,20}=9.00^{* *}$ & $F_{2,334}=3.27^{*}$ & - & 0.01 & 0.10 \\
\hline \multicolumn{7}{|l|}{ Herbivorous gastropods } \\
\hline Cookia sulcata (all depths) & $F_{2,20}=7.34^{* *}$ & $F_{1,20}=25.12^{* * *}$ & $F_{3,420}=3.43^{*}$ & $F_{3,420}=4.07^{* *}$ & $0.28^{*}$ & $0.18^{* * *}$ \\
\hline $\begin{array}{l}\text { Cellana stellifera } \\
\text { (excl. } 7-9 \text { and }>10 \mathrm{~m})\end{array}$ & $F_{2,20}=15.39^{* * *}$ & $F_{1,20}=7.26^{*}$ & $F_{1,214}=13.12^{* * *}$ & $F_{1,214}=5.40^{*}$ & $0.82^{*}$ & -0.06 \\
\hline Trochus viridis $(\text { excl. }<2 \mathrm{~m})^{\mathrm{a}}$ & $F_{2,20}=0.80$ & $F_{1,20}=1.54$ & $F_{2,298}=8.13^{* * *}$ & $F_{2,298}=3.27^{*}$ & $0.56^{* *}$ & $0.20^{* *}$ \\
\hline $\begin{array}{l}\text { Cantharidus purpureus } \\
\text { (excl. }<2 \mathrm{~m})\end{array}$ & $F_{2,20}=0.56$ & $F_{1,20}=0.29$ & $F_{2,302}=30.67^{* * *}$ & $F_{2,302}=6.54^{* *}$ & $0.82^{* *}$ & 0.11 \\
\hline \multicolumn{7}{|l|}{$\operatorname{Algae}^{b}$} \\
\hline Ecklonia radiata (all depths) & $F_{2,20}=5.16^{*}$ & $F_{1,20}=3.02$ & $F_{3,420}=50.20^{* * *}$ & $F_{3,420}=8.32^{* * *}$ & $0.22^{* *}$ & $0.12^{*}$ \\
\hline $\begin{array}{l}\text { C. maschalocarpum } \\
(\text { excl. } 7-9 \text { and }>10 \mathrm{~m})\end{array}$ & $F_{2,20}=3.23^{0.06}$ & $F_{1,20}=1.62$ & $F_{1,215}=46.30^{* * *}$ & - & $0.29^{*}$ & $0.33^{* * *}$ \\
\hline
\end{tabular}

coralline turf was higher at reserve sites, while at nonreserve sites there was more filamentous algae and also C. flexuosum (Table 4). Within the other depth ranges, there were some clear differences for particu- lar species. For example, in the shallow depth range $(<2 \mathrm{~m})$ reserve sites had a much higher biomass of $C$. angustifolium and Pterocladia lucida. Nevertheless, there was no significant difference in overall algal

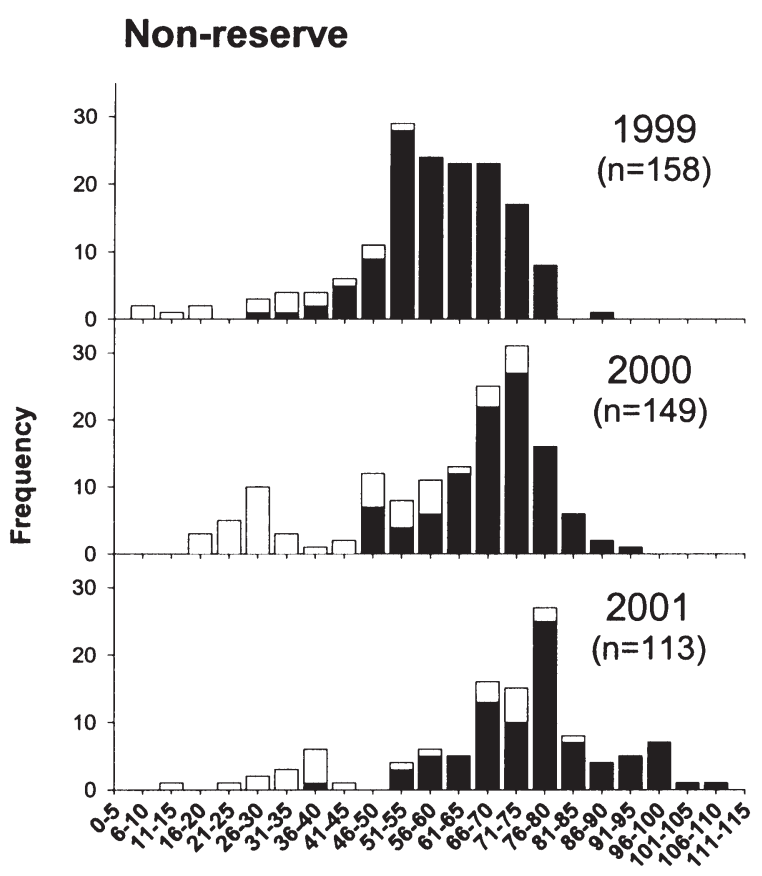

\section{Reserve}

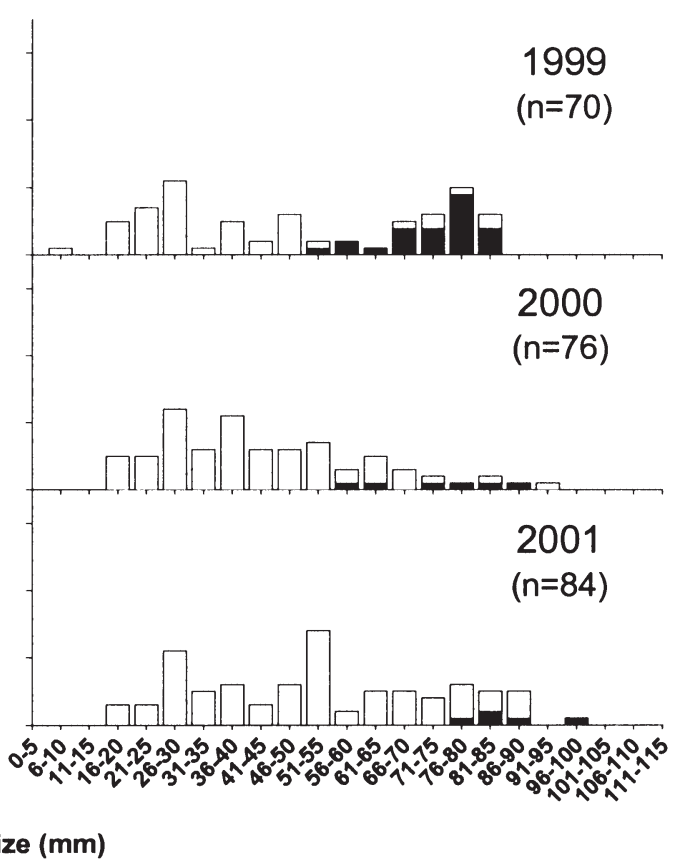

Fig. 6. Evechinus chloroticus size frequency distribution for reserve (4 sites) and non-reserve (4 sites) populations between 1999 and 2001. Samples pooled across all depths. Filled bars indicate exposed individuals; open bars indicate cryptic urchins 
Table 4. The main algal species separating reserve and non-reserve sites in the 4 to $6 \mathrm{~m}$ depth stratum from 2001 sampling. The top 10 species are ranked according to their contribution to the difference between reserve and non-reserve sites. Note that in some cases species refers to an algal group, e.g. Filamentous. For each species the average biomass ( $\mathrm{g} \mathrm{m}^{-2} \pm \mathrm{SE}$ ) for reserve and non-reserve sites, the average dissimilarity (Dis), the ratio of average dissimilarity and standard deviation (Dis/SD), the percent contribution to overall dissimilarity (\%Dis), the cumulative percentage $(\Sigma \%$ Dis $)$ and the percent contribution to total algal biomass $(\% \mathrm{~B})$ at that depth are presented

\begin{tabular}{|c|c|c|c|c|c|c|c|}
\hline Species & Reserve & Non-reserve & Dis & Dis/SD & $\%$ Dis & $\Sigma \%$ Dis & $\% \mathrm{~B}$ \\
\hline \multicolumn{8}{|l|}{ Average dissimilarity $61.31 \%$} \\
\hline Ecklonia radiata & $205.1 \pm 42.1$ & $29.4 \pm 16.4$ & 15.4 & 1.74 & 25.2 & 25.2 & 45.5 \\
\hline Carpophyllum maschalocarpum & $120.3 \pm 30.6$ & $5.9 \pm 2.6$ & 13.0 & 1.72 & 21.2 & 46.4 & 24.4 \\
\hline Filamentous & $0.3 \pm 0.1$ & $7.0 \pm 1.2$ & 7.0 & 1.59 & 11.5 & 57.8 & 1.4 \\
\hline Coralline turf & $72.0 \pm 13.7$ & $43.2 \pm 11.3$ & 4.9 & 1.27 & 8.1 & 65.9 & 22.3 \\
\hline Crustose corallines & $7.3 \pm 0.4$ & $3.3 \pm 0.5$ & 3.6 & 1.42 & 5.9 & 71.8 & 2.1 \\
\hline Red turf & $1.0 \pm 0.2$ & $1.1 \pm 0.6$ & 2.9 & 1.33 & 4.8 & 76.6 & 0.4 \\
\hline Pterocladia lucida & $1.3 \pm 1.0$ & $3.3 \pm 1.8$ & 2.4 & 0.53 & 3.9 & 80.5 & 0.9 \\
\hline C. flexuosum & 0 & $3.9 \pm 2.5$ & 2.2 & 0.5 & 3.6 & 84.1 & 0.8 \\
\hline Codium convolutum & $0.5 \pm 1.2$ & $0.9 \pm 0.2$ & 2.8 & 0.86 & 3.4 & 87.5 & 0.3 \\
\hline Sargassum sinclairii & $0.7 \pm 0.4$ & $0.9 \pm 0.5$ & 2.3 & 0.91 & 3.3 & 90.8 & 0.3 \\
\hline Others (6 spp.) & 6.2 & 2.3 & & & 9.1 & & 1.6 \\
\hline
\end{tabular}

assemblages between reserve and non-reserve sites at these depths.

Overall algal assemblages were stable over time (1999 to 2001) at all depths (Table 5B). However, in the
4 to $6 \mathrm{~m}$ depth range the effect of year was marginally insignificant (NP-MANOVA, $p=0.06$, Table 5B) and changes were apparent in the similarity of algal communities at reserve and non-reserve sites (Fig. 8).
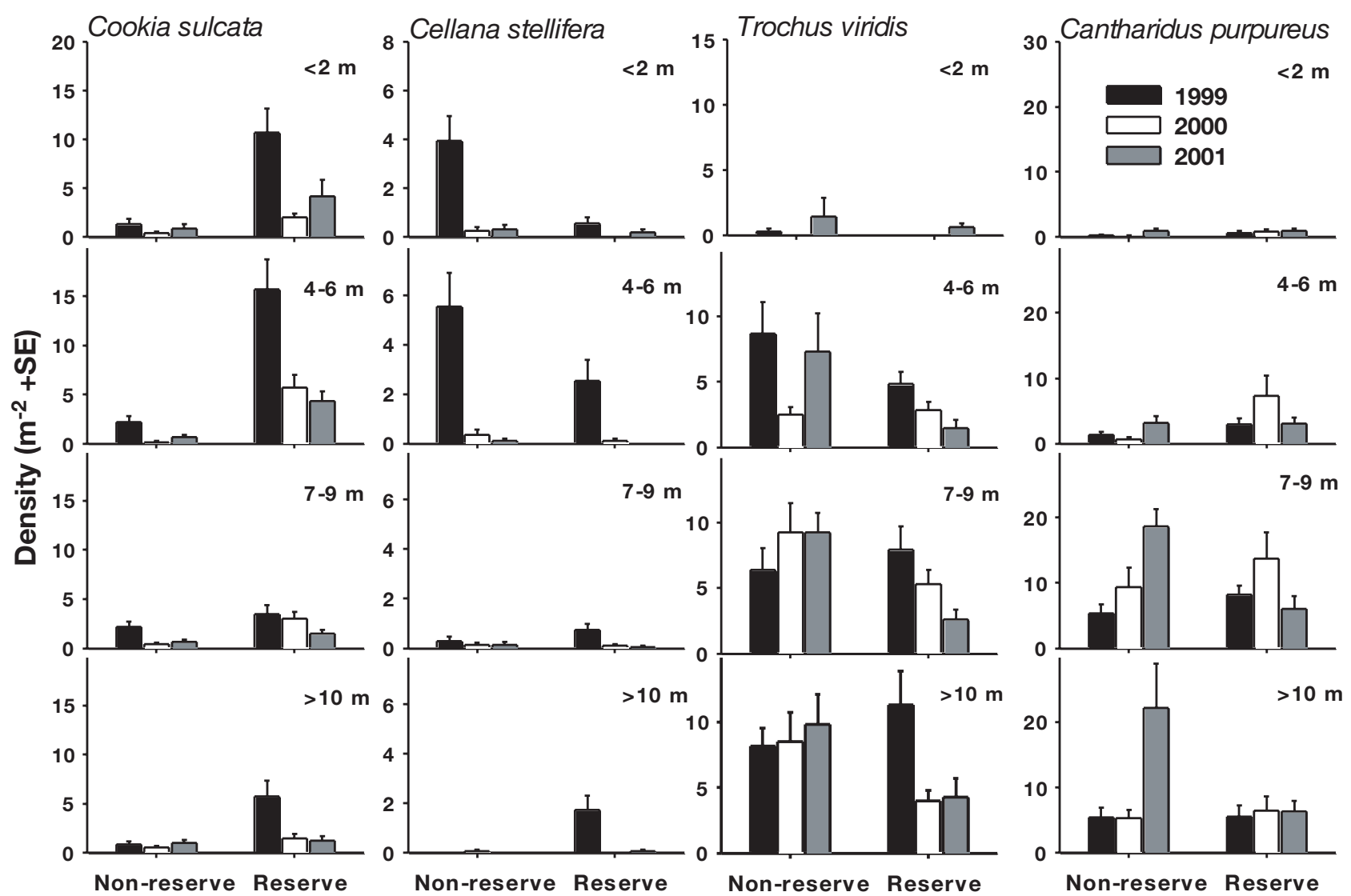

Fig. 7. Density of the 4 most common gastropod species at reserve and non-reserve sites between 1999 and 2001 . Note differing $y$-axis scales 
Reserve sites grew more similar (similarity increased from 56.2 to $73.8 \%$ ), as all sites became dominated by the large brown algae Ecklonia radiata and $C$. maschalocarpum, while sites outside the reserve became more different (similarity decreased from 65.2 to $45.2 \%$ ), due to the increase in large brown algae at Rodney South. At Kempts Beach there was high variation among samples each year (Fig. 8) due to the position of the urchin barren-kelp forest border. While the overall difference in algal communities between reserve and non-reserve sites was consistent from 1999 to 2001 (Fig. 8), changes were apparent in the dominant species.

Dominant species. Ecklonia radiata and Carpophyllum maschalocarpum (Fig. 9) were the greatest contributors to total algal biomass each year $(67.6 \pm 1.2$ and $22.4 \pm 1.4 \%$, respectively) and were largely responsible for the differences at 4 to $6 \mathrm{~m}$ between reserve and non-reserve sites (Table 4). E. radiata biomass varied significantly with year (Table 3 ). A large increase in E. radiata biomass across all depths was apparent between 1999 and 2000. There was no overall difference between reserve and non-reserve sites, but the effect of status changed with depth (Table 3). Significant differences with status occurred between 4 and $6 \mathrm{~m}\left(F_{1,20}=21.99, \mathrm{p}<0.01\right)$, where E. radiata biomass was $12.5\left(\mathrm{CL}_{95}=4.4,35.9\right)$ times higher at reserve sites, and deeper than $10 \mathrm{~m}\left(F_{1,14}=6.03, \mathrm{p}=0.03\right)$, where the biomass was actually $2.0(1.2,3.4)$ times higher at the non-reserve sites. This effect was largely due to the high biomass of $E$. radiata at 2 non-reserve sites, Mathesons Island and Nordic Reef, where the plants were larger than those at other sites.

Carpophyllum maschalocarpum dominated the shallowest depth stratum, was common at 4 to $6 \mathrm{~m}$ depth and rare in the deeper strata (Fig. 9). While biomass varied significantly between depths there was no overall difference among years or with reserve status (Table 3). These patterns were consistent at depths
Table 5. Differences in algal communities (A) between reserve and non-reserve sites and (B) between 1999 and 2001. Results from NP-MANOVA; data were transformed to $\ln (x+1)$; analysis based on Bray-Curtis dissimilarities; restricted permutation of raw data with 4999 permutations. The tests for the effect of Status are presented for the 2001 data

\begin{tabular}{|c|c|c|c|c|}
\hline & df & MS & $F$ & $\mathrm{p}$ \\
\hline \multicolumn{5}{|c|}{ (A) Reserve status } \\
\hline \multicolumn{5}{|c|}{$0-2 \mathrm{~m}$} \\
\hline Status & 1 & 6655.4 & 1.96 & 0.06 \\
\hline Site(Status) & 6 & 3390.5 & 3.89 & $<0.01$ \\
\hline \multicolumn{5}{|l|}{$4-6 \mathrm{~m}$} \\
\hline Status & 1 & 22219.7 & 8.07 & 0.03 \\
\hline Site(Status) & 6 & 2754.9 & 4.03 & $<0.01$ \\
\hline \multicolumn{5}{|l|}{$7-9 \mathrm{~m}$} \\
\hline Status & 1 & 3446.8 & 1.60 & 0.09 \\
\hline Site(Status) & 6 & 2150.9 & 5.33 & $<0.01$ \\
\hline \multicolumn{5}{|l|}{$>10 \mathrm{~m}$} \\
\hline Status & 1 & 2576.6 & 1.30 & $0.29^{\mathrm{a}}$ \\
\hline Site(Status) & 6 & 1988.8 & 8.49 & $<0.01$ \\
\hline \multicolumn{5}{|c|}{ (B) Time 1999-2001 } \\
\hline \multicolumn{5}{|c|}{$0-2 \mathrm{~m}$} \\
\hline Time & 2 & 5522.9 & 1.43 & 0.12 \\
\hline Site(Time) & 21 & 3857.9 & 4.92 & $<0.01$ \\
\hline \multicolumn{5}{|l|}{$4-6 \mathrm{~m}$} \\
\hline Time & 2 & 11868.6 & 2.27 & 0.06 \\
\hline Site(Time) & 21 & 5233.4 & 8.13 & $<0.01$ \\
\hline \multicolumn{5}{|l|}{$7-9 \mathrm{~m}$} \\
\hline Time & 2 & 1597.6 & 0.96 & 0.48 \\
\hline Site(Time) & 21 & 1667.6 & 4.78 & $<0.01$ \\
\hline \multicolumn{5}{|l|}{$>10 \mathrm{~m}$} \\
\hline Time & 2 & 2210.6 & 0.83 & 0.58 \\
\hline Site(Time) & 15 & 2668.7 & 9.93 & $<0.01$ \\
\hline
\end{tabular}

$<2 \mathrm{~m}$, but at 4 to $6 \mathrm{~m} \mathrm{C}$. maschalocarpum biomass increased significantly between years $\left(F_{2,20}=4.12, \mathrm{p}=\right.$ $0.03)$ and was $28.5\left(\mathrm{CL}_{95}=7.4,109.9\right)$ times higher at reserve sites $\left(F_{1,20}=23.6, \mathrm{p}<0.01\right)$.
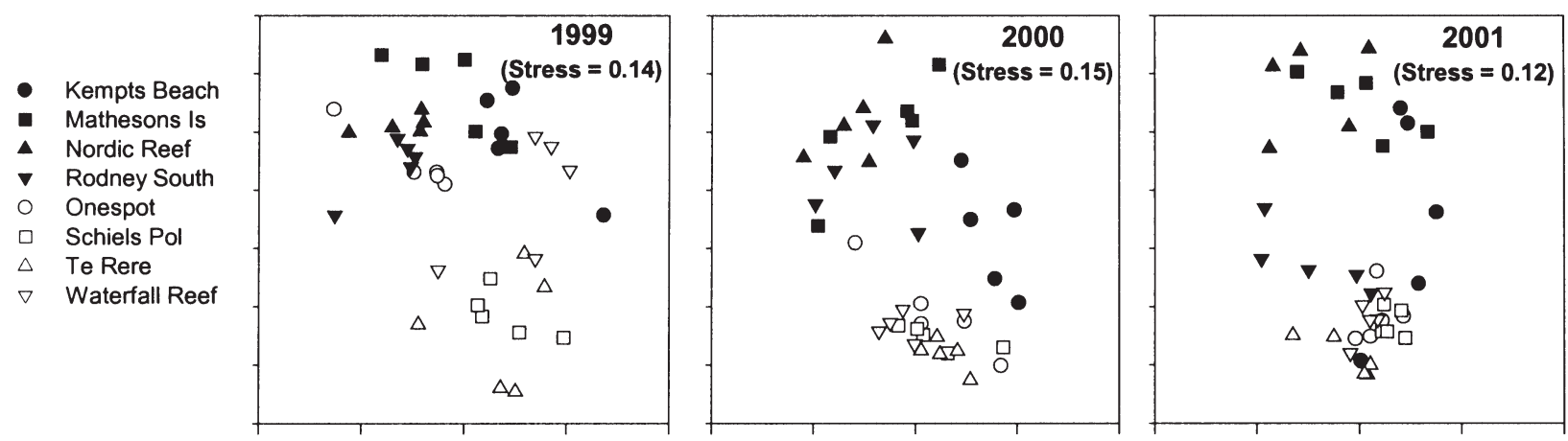

Fig. 8. Temporal changes in algal communities for the 4 to $6 \mathrm{~m}$ depth range between 1999 and 2001. MDS ordination based on Bray-Curtis similarities of quadrat data from each year. Data were fourth-root transformed. Open symbols indicate reserve sites, and closed symbols non-reserve sites 


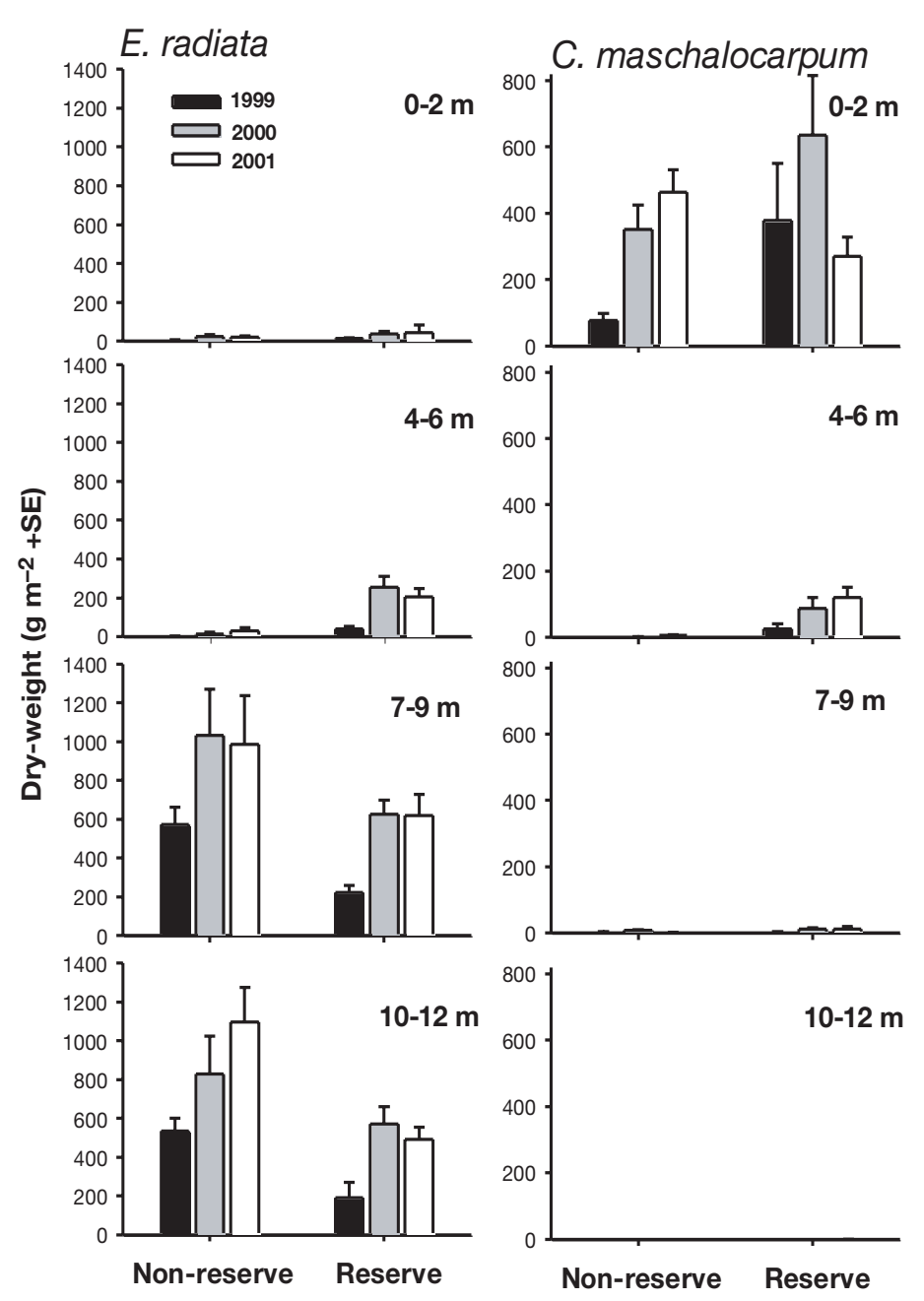

Fig. 9. Biomass of Ecklonia radiata and Carpophyllum maschalocarpum at reserve and non-reserve sites between 1999 and 2001

\section{DISCUSSION}

\section{Long-term habitat change in the Leigh Reserve}

The transition from urchin barrens to kelp has continued in the Leigh Reserve since 1996, consistent with the top-down control of urchins by predators in this system (Babcock et al. 1999, Shears \& Babcock 2002). In 1978 the urchin barrens habitat dominated between depths of 5 and $9 \mathrm{~m}$ (Ayling 1978). Now, all of Ayling's (1978) permanent sites originally classified as 'rockflats' (= 'urchin barrens'; Table 1) are dominated by large brown algae. In 1996 the permanent site located on Waterfall Reef persisted as urchin barrens (Babcock et al. 1999), as it had done for over 25 yr (Ayling 1981). Cole \& Keuskamp (1998) recorded a $10 \mathrm{yr}$ decline in density of the sea urchin Evechinus chloroticus at this site prior to 1998. This decline has continued in 1999 and 2000, and this area is now dominated by large brown algae (Fig. 3).

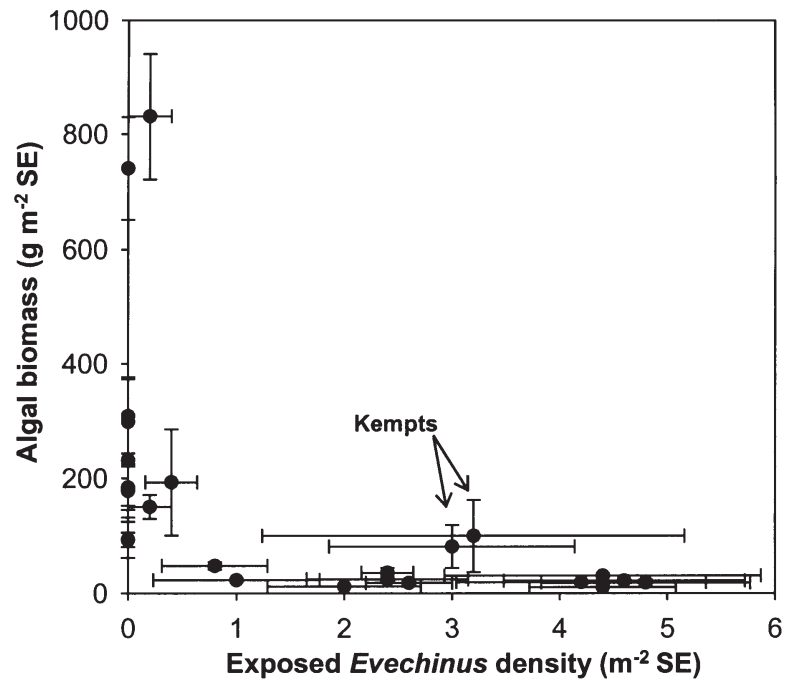

Fig. 10. Relationship between total algal biomass and exposed urchin density in the 4 to $6 \mathrm{~m}$ depth range. Data are site averages ( $\mathrm{n}=5$ quadrats) at each sampling time (1999-2001). The 2 outliers are from Kempts Beach, where sampling was carried out on the kelp forest border, where urchins are in close proximity to Ecklonia radiata

Permanent sites located in shallower $(<5 \mathrm{~m})$ and deeper $(>10 \mathrm{~m})$ water have historically been dominated by large brown algae, and these areas have remained relatively stable since 1978. At shallow depths sea urchins are typically cryptic, due to higher water motion and also a more abundant supply of drift algae (Lissner 1980, Rogers-Bennett et al. 1995), and have limited grazing effects on algae. Cryptic behaviour also reduces susceptibility to predation, and subsequently in the shallow permanent sites Evechinus chloroticus remains at moderate but variable densities. Deeper permanent sites are dominated by monospecific stands of Ecklonia radiata, and E. chloroticus occurs at very low densities; consequently, these areas have remained stable since 1978. Low numbers of sea urchins in kelp forests have been attributed to low recruitment (Duggins et al. 1990), low juvenile survivorship (Andrew \& Choat 1985), physical abrasion of algae on adult urchins (Konar 2000) and predators associated with kelp (Breen \& Mann 1976). At the permanent sites sampled there were no apparent longterm effects on $E$. radiata populations resulting from the widespread dieback event recorded in 1992-93 (Cole \& Babcock 1996).

While data are lacking for the permanent sites between 1978 and 1994, trends in habitat change have continued along the same trajectory since 1994. In other systems these habitats show long-term persistence, and transitions between barrens and kelp are thought to occur irregularly without any detectable periodicity (reviews by Harrold \& Pearse 1987, Chap- 
man \& Johnson 1990, but see Hagen 1995). The dominant algae in this system (Ecklonia radiata and Carpophyllum maschalocarpum) are both relatively resilient long-lived species (Novaczek 1980, Schiel 1985, T. Haggitt unpubl. data), and algal habitats appear stable once established. It is therefore unlikely that the depth-specific changes seen are a result of short-term or cyclical patterns in abundance of major structural species. This long-term data on urchin and kelp abundances at specific sites have proved highly valuable in identifying the trophic cascades responsible for shifts between these alternate states.

\section{Contrasts between reserve and non-reserve sites}

Differences in both grazer and algal communities between reserve and non-reserve sites are consistent with the direct and indirect effects associated with higher abundances of urchin predators (Kelly et al. 2000, Willis et al. 2000, in press) at reserve sites, thus providing evidence for a trophic cascade. The greater cover of urchin barrens habitat and higher urchin densities at unprotected sites seen in this study have previously been attributed to lower levels of predation on urchins compared to reserve sites (Babcock et al. 1999, Shears \& Babcock 2002). As seen in changes at permanent sites, these effects are depth-specific, and in this case reserve-related differences were only apparent in the 4 to $6 \mathrm{~m}$ depth stratum. In this depth range exposed Evechinus chloroticus, which are responsible for maintaining the urchin barrens habitat (Shears \& Babcock 2002), were rare in the reserve, and the biomass of Ecklonia radiata and C. maschalocarpum was 12.5 and 28.5 times higher at reserve than non-reserve sites.

The size structure of urchins also differed between reserve and non-reserve sites. Previous studies suggested that bimodal population structures in the Leigh reserve and Tawharanui Marine Park resulted from high levels of size-specific predation (Cole \& Keuskamp 1998, Shears \& Babcock 2002). In our study reserve populations were weakly bimodal in 1999, but in subsequent years this bimodality was lost due to the continual decline in abundance of large exposed urchins. Within the reserve, proportionally more urchins exhibited cryptic behaviour than at non-reserve sites, and crypsis was also maintained by larger individuals. Cryptic behaviour of urchins at reserve sites is likely to be due to a combination of factors, including a more abundant supply of drift algae that reduces the need for active foraging (Harrold \& Reed 1985), abrasion by macroalgae (Konar 2000), and greater levels of predation (Shears $\&$ Babcock 2002)
In addition to trophic cascades, evidence for further, indirect effects (Menge 1995) is provided by differences in the abundance of the limpet Cellana stellifera and the turbinid gastropod Cookia sulcata between reserve and non-reserve sites. The density of C. sulcata was 3 times higher at reserve sites. This may be related to the higher cover of coralline turf seen at reserve sites associated with reduced urchin densities (Shears \& Babcock 2002). Coralline turf is a major component of the diet of C. sulcata (Keestra 1987), and the abundance of $C$. sulcata is generally positively correlated with the cover of coralline turf (N. T. Shears unpubl. data). Such indirect effects may provide an example of habitat facilitation (Menge 1995), whereby predators indirectly improve the habitat for C. sulcata through the removal of Evechinus chloroticus.

Conversely, densities of Cellana stellifera were 2.5 times lower in the reserve than at non-reserve sites. This is consistent with patterns recorded in the Aleutian Islands, where limpets occur at higher densities where sea otters are absent (Simenstad et al. 1978). While the lower abundance of $C$. stellifera in the reserve may be related to the higher abundance of predators, the grazing activity of Evechinus chloroticus maintains a suitable substratum (crustose coralline algae) for the attachment and movement of C. stellifera (Andrew \& Choat 1982). Experimental removals of urchins typically result in increased biomass of turfing algae and a decline in limpet densities (Andrew \& Choat 1982, Fletcher 1987, Andrew \& Underwood 1993, N. T. Shears unpubl. data). Therefore, the indirect effect of increased predator density is a lower density of limpets in the reserve, which could be interpreted as an example of habitat inhibition (cf. Menge 1995).

\section{Temporal consistency of reserve-related differences}

Differences in community structure between reserve and non-reserve sites were stable from 1999 to 2001, consistent with a trophic cascade. While this spatial contrast indicates stability of long-term changes, there were some short-term changes in urchin density and algal communities at both reserve and non-reserve sites. In 1999 exposed urchins and urchin barrens habitat occurred in the 4 to $6 \mathrm{~m}$ depth range at the sites in the eastern part of the reserve (Waterfall and Onespot). However, in subsequent years Evechinus chloroticus declined below an apparent threshold density, allowing macroalgae to dominate, consistent with patterns seen at the permanent site at Waterfall Reef. By 2001 the urchin barrens habitat was absent, and exposed urchins were rare at reserve sites. Comparisons of exposed urchin density and algal biomass at 
sites in this study (Fig. 10) revealed that the threshold density of exposed urchins required to maintain the barrens habitat appears to be around $1 \mathrm{~m}^{-2}$, below which macroalgae quickly colonize. Breen \& Mann (1976) estimated that kelp could not recolonize barren areas in Nova Scotia when urchin biomass exceeds $150 \mathrm{~g} \mathrm{~m}^{-2}$ (wet weight). This is consistent with our study, in which the average test diameter $(D)$ of exposed urchins was $69.0 \pm 0.7 \mathrm{~mm}$, equating to a wet weight of $134.2 \mathrm{~g}$ (weight $=0.000843 D^{2.8288}$; R. Taylor unpubl. data). It is not clear what the threshold urchin density would be for the reversal of kelp to urchin barrens and also not clear is the time-scale of such transitions. Ayling (1981) suggested that only when urchin densities increased above $\sim 6 \mathrm{~m}^{-2}$ was grazing intensity sufficient to allow the formation of urchin barrens. Similarly, in Nova Scotia a threshold urchin biomass of $2 \mathrm{~kg} \mathrm{~m}^{-2}$ (wet weight) is necessary to initiate destructive grazing of kelp forests (Breen \& Mann 1976, Scheibling et al. 1999). In our study this would equate to a density of exposed E. chloroticus of $14.9 \mathrm{~m}^{-2}$. Such densities are currently rare on reefs in the Leigh area (N. T. Shears pers. obs.).

Rapid declines in urchin densities were recorded at 3 of the non-reserve sites associated with a local-scale urchin mortality event observed around Leigh in summer 1999-2000 (J. Walker \& R. Babcock unpubl. data). However, only at 1 of these sites (Rodney South) did urchin density drop below $1 \mathrm{~m}^{-2}$, allowing macroalgae to establish. The urchin barrens habitat remained stable at the other sites among years despite reduced urchin densities. Mass mortality of Evechinus chloroticus has not been previously documented in northeastern New Zealand, but the rapid declines and the symptoms of 'sick' and dying urchins are consistent with disease in stronglyocentrotid species (Shimizu et al. 1995). Urchins exhibiting these symptoms were only observed at sites outside the reserve. Large declines in Cellana stellifera also occurred between 1999 and 2001, which is consistent with a reduction in urchin density (Andrew \& Choat 1982). Recovery of urchins from such die-offs is likely given the small-scale of mortalities. In Jamaica recovery of Diadema antillarum has been reported (Edmunds \& Carpenter 2001) even after the large-scale mass mortalities there (Lessios 1988).

Over the duration of our study (1999 to 2001) climatic conditions were in a weak La Niña phase, with consistently warmer than average summer water temperatures (J. Evans unpubl. data). This may have been related to the occurrence of the urchin die-off seen at some non-reserve sites. Urchin mortalities in other parts of the world have also been associated with higher than normal water temperatures (Scheibling \& Hennigar 1997). The long-term trends seen in the reserve at Leigh, however, do not appear to be corre- lated with any changes in oceanographic conditions. Since 1978 there have been no clear trends in sea temperature, with both warmer and colder than average years (J. Evans, Leigh Marine Laboratory, unpubl. data). Furthermore, the contrasting states between reserve and non-reserve sites discount oceanographic changes as a mechanism for explaining long-term changes at reserve sites.

\section{CONCLUSIONS}

The findings from this study provide further evidence for a trophic cascade on subtidal reefs in northeastern New Zealand:

- The continued, long-term decline in urchin-dominated habitats and increase in algal habitats at reserve sites is consistent with top-down control of predators on assemblage structure.

- Conspicuous indirect effects on algae are apparent between reserve (high predators) and non-reserve (low predators) sites. Other indirect interactions such as habitat facilitation and inhibition at 2 trophic levels below top predators have also been observed.

- The contrasts in assemblage structure between reserve and non-reserve sites have generally remained stable over the last 3 yr.

In northeastern New Zealand the urchin barrens habitat can persist for long periods while urchin numbers decline, due to the low threshold density of urchins required to maintain the habitat. Predation is highest on juvenile urchins, while only low rates of predation occur on the large urchins, which are responsible for maintaining the habitat (Shears \& Babcock 2002). Therefore the indirect effects of increases in predator abundance associated with marine reserve protection on benthic community structure have occurred over a long period in the Leigh reserve. The trophic effects of other disturbances that directly affect adult urchins (e.g. disease, harvesting) can operate over much shorter time scales, which result in rapid changes in assemblage structure such as those observed outside the reserve. Trajectories of habitat change at non-reserve sites will be of continued interest along with the degree of persistence of kelp communities in the reserve.

Acknowledgements. Many thanks to Rob Russell, Jarrod Walker, Tim Haggitt, David Feary and James Williams for their valuable assistance on, off and under the water. We are very grateful to Gregor MacAskill and Samara Eaton, who assisted in the development of a large database used for managing the data collected in this study. The Leigh Lab Discussion Group along with Drs Russell Cole, Richard Taylor, Nick Tolimieri, Trevor Willis and 4 anonymous reviewers provided helpful comments on the manuscript. Thanks to Drs Marti 
Anderson and Russell Millar for assisting with statistical matters. Thanks also to the staff and students at the Leigh Marine Laboratory. This study was funded by the Department of Conservation, Research Investigation No. NRO/02/01, Cape Rodney-Okakari Pt Marine Reserve Monitoring Program.

\section{LITERATURE CITED}

Anderson MJ (2001) A new method for non-parametric multivariate analysis of variance. Aust Ecol 26:32-46

Andrew NL, Choat JH (1982) The influence of predation and conspecific adults on the abundance of juvenile Evechinus chloroticus (Echinoidea: Echinometridae). Oecologia 54: 80-87

Andrew NL, Choat JH (1985) Habitat related differences in the growth and survivorship of juvenile echinoids. Mar Ecol Prog Ser 27:155-161

Andrew NL, Underwood AJ (1993) Density-dependent foraging in the sea urchin Centrostephanus rodgersii on shallow subtidal reefs in New South Wales, Australia. Mar Ecol Prog Ser 99:89-98

Ayling AM (1978) Cape Rodney to Okakari Point Marine Reserve Survey. Leigh Laboratory Bulletin 1

Ayling AM (1981) The role of biological disturbance in temperate subtidal encrusting communities. Ecology 62: 830-847

Babcock RC, Kelly S, Shears NT, Walker JW, Willis TJ (1999) Changes in community structure in temperate marine reserves. Mar Ecol Prog Ser 189:125-134

Bergquist PL (1960) Notes on the marine algal ecology of some exposed rocky shores of Northland, New Zealand. Bot Mar 1:86-94

Breen PA, Mann KH (1976) Destructive grazing of kelp by sea urchins in eastern Canada. J Fish Res Board Can 33: 1278-1283

Chapman ARO, Johnson CR (1990) Disturbance and organization of macroalgal assemblages in the Northwest Atlantic. Hydrobiologia 192:77-121

Choat JH, Andrew NL (1986) Interactions among species in a guild of subtidal benthic herbivores. Oecologia 68:387-394

Choat JH, Schiel DR (1982) Patterns of distribution and abundance of large brown algae and invertebrate herbivores in subtidal regions of northern New Zealand. J Exp Mar Biol Ecol 60:129-162

Clarke KR, Warwick RM (1994) Change in marine communities: an approach to statistical analysis and interpretation. Natural Environment Research Council, Plymouth

Cole RG, Babcock RC (1996) Mass mortality of a dominant kelp (Laminariales) at Goat Island, north-eastern New Zealand. Mar Freshw Res 47:907-911

Cole RG, Keuskamp D (1998) Indirect effects of protection from exploitation: patterns from populations of Evechinus chloroticus (Echinoidea) in northeastern New Zealand. Mar Ecol Prog Ser 173:215-226

Dayton PK, Tegner MJ, Edwards PB, Riser KL (1998) Sliding baselines, ghosts, and reduced expectations in kelp forest communities. Ecol Appl 8:309-322

Duggins DO, Eckman JE, Sewell AT (1990) Ecology of understory kelp environments. 2. Effects of kelps on recruitment of benthic invertebrates. J Exp Mar Biol Ecol 143:27-45

Ebeling AW, Laur DR, Rowley RJ (1985) Severe storm disturbances and reversal of community structure in a southern California kelp forest. Mar Biol 84:287-294

Edgar GJ, Barrett NS (1997) Short term monitoring of biotic change in Tasmanian marine reserves. J Exp Mar Biol Ecol 213:261-279
Edgar GJ, Barrett NS (1999) Effects of the declaration of marine reserves on Tasmanian reef fishes, invertebrates and plants. J Exp Mar Biol Ecol 242:107-144

Edmunds PJ, Carpenter RC (2001) Recovery of Diadema antillarum reduces macroalgal cover and increases abundance of juvenile corals on a Caribbean reef. Proc Natl Acad Sci USA 98:5067-5071

Estes JA, Duggins DO (1995) Sea otters and kelp forests in Alaska: Generality and variation in a community ecological paradigm. Ecol Monogr 65:75-100

Fletcher WJ (1987) Interactions among subtidal Australian sea urchins, gastropods and algae: effects of experimental removals. Ecol Monogr 57:89-109

Hagen NT (1995) Recurrent destructive grazing of successionally immature kelp forests by green sea urchins in Vestfjorden, Northern Norway. Mar Ecol Prog Ser 123:95-106

Hairston NG, Smith FE, Slodbodkin LB (1960) Community structure, population control and competition. Am Nat 94: 421-425

Harrold C, Pearse JS (1987) The ecological role of echinoderms in kelp forests. Echino Stud 2:137-233

Harrold C, Reed DC (1985) Food availability, sea urchin grazing, and kelp forest community structure. Ecology 66: 1160-1169

Jackson JBC, Kirby MX, Berger WH, Bjorndal KA, Botsford LW and 14 others (2001) Historical overfishing and the recent collapse of coastal ecosystems. Science 293:629-638

Jennings S, Kaiser MJ (1998) The effects of fishing on marine ecosystems. Adv Mar Biol 34:201-352

Keestra BH (1987) The ecology of Cookia sulcata, with special reference to the coralline flats habitat, and associated guild of subtidal invertebrate grazers. MSc thesis, University of Auckland

Kelly S, Scott D, MacDiarmid AB, Babcock RC (2000) Spiny lobster, Jasus edwardsii, recovery in New Zealand marine reserves. Biol Conserv 92:359-369

Konar B (2000) Seasonal inhibitory effects of marine plants on sea urchins: structuring communities the algal way. Oecologia 125:208-217

Lawrence JM (1975) On the relationships between marine plants and sea urchins. Oceanogr Mar Biol Annu Rev 13: 213-286

Lessios HA (1988) Mass mortality of Diadema antillarum in the Caribbean: what have we learned? Annu Rev Ecol Syst 19:371-393

Lissner AL (1980) Some effects of turbulence on the activity of the sea urchin Centrostephanus coronatus Verill. J Exp Mar Biol Ecol 48:185-193

Littell RC, Milliken GA, Stroup WW, Wolfinger RD (1996) SAS system for mixed models. SAS Institute, Cary, NC

Menge BA (1995) Indirect effects in marine intertidal interaction webs: patterns and importance. Ecol Monogr 65: $21-74$

Novaczek I (1980) The development and phenology of Ecklonia radiata. $\mathrm{PhD}$ thesis, University of Auckland

Pace ML, Cole JE, Carpenter SR, Kitchell JF (1999) Trophic cascades revealed in diverse ecosystems. Trends Ecol Evol $14: 483-488$

Pauly D, Christensen V, Dalsgaard J, Froese R, Torres FJ (1998) Fishing down marine food webs. Science 279:860-863

Pinnegar JK, Polunin NVC, Francour P, Badalamenti F and 7 others (2000) Trophic cascades in benthic marine ecosystems: lessons for fisheries and protected-area management. Environ Conserv 27:179-200

Polis GA, Sears ALW, Huxel GR, Strong DR, Maron J (2000) When is a trophic cascade a trophic cascade? Trends Ecol Evol 15:473-475 
Rogers-Bennett L, Bennett WA, Fastenau HC, Dewees CM (1995) Spatial variation in red sea urchin reproduction and morphology -implications for harvest refugia. Ecol Appl 5:1171-1180

Sala E, Boudouresque CF, Harmelin-Vivien M (1998) Fishing, trophic cascades, and the structure of algal assemblages: evaluation of an old but untested paradigm. Oikos 82: 425-439

Scheibling RE (1996) The role of predation in regulating sea urchin populations in eastern Canada. Oceanol Acta 19: 421-430

Scheibling RE, Hennigar AW (1997) Recurrent outbreaks of disease in sea urchins Strongylocentrotus droebachiensis in Nova Scotia: evidence for a link with large-scale meteorologic and oceanographic events. Mar Ecol Prog Ser 152:155-165

Scheibling RE, Hennigar AW, Balch T (1999) Destructive grazing, epiphytism, and disease: the dynamics of sea urchin-kelp interactions in Nova Scotia. Can J Fish Aquat Sci 56:2300-2314

Schiel DR (1985) Growth survival and reproduction of two species of marine algae at different densities in natural stands. J Ecol 73:199-218

Shears NT, Babcock RC (2000) Classification and preliminary productivity estimates of rocky coastal community types: northeastern New Zealand. Report to Department of Conservation, Wellington

Shears NT, Babcock RC (2002) Marine reserves demonstrate top-down control of community structure on temperate reefs. Oecologia 132:131-142

Shimizu M, Takaya Y, Ohsaki S, Kawamata K (1995) Gross and histopathological signs of the spotting disease in the sea urchin Strongylocentrotus intermedius. Fish Sci 61: 608-613

Editorial responsibility: Otto Kinne (Editor),

Oldendorf/Luhe, Germany
Simenstad CA, Estes JA, Kenyon KW (1978) Aleuts, sea otters, and alternate stable-state communities. Science 200:403-411

Steneck RS (1997) Fisheries-induced biological changes to the structure and function of the Gulf of Maine ecosystem. In: Proceedings of the Gulf of Maine Ecosystem Dynamics Scientific Symposium and Workshop. RARGOM Report 91-1. Regional Association for Research in the Gulf of Maine, Hanover, NH, p 151-165

Taylor RB (1998) Density, biomass and productivity of animals in four subtidal rocky reef habitats: the importance of small mobile invertebrates. Mar Ecol Prog Ser 172:37-51

Tegner MJ, Dayton PK (2000) Ecosystem effects of fishing in kelp forest communities. ICES J Mar Sci 57:579-589

Vadas RL, Steneck RS (1995) Overfishing and inferences in kelpsea urchin interactions. In: Skjoldal HR, Hopkins C, Erickstad KE, Leinaas HP (eds) Ecology of fjords and coastal waters. Elsevier Science, BV, Amsterdam, p 509-524

Wharton WG, Mann KH (1981) Relationship between destructive grazing by the sea urchin, Strongylocentrotus droebachiensis, and the abundance of American lobster, Homarus americanus, on the Atlantic Coast of Nova Scotia. Can J Fish Aquat Sci 38:1339-1349

Willis TJ, Millar RB (2001) Modified hooks reduce incidental mortality of snapper (Pagrus auratus: Sparidae) in the New Zealand commercial longline fishery. ICES J Mar Sci 58: 830-841

Willis TJ, Millar RB, Babcock RC (2000) Detection of spatial variability in relative density of fishes: comparison of visual census, angling, and baited underwater video. Mar Ecol Prog Ser 198:249-260

Willis TJ, Millar RB, Babcock RC (in press) Responses of snapper Pagrus auratus (Sparidae) to marine reserve protection in northeastern New Zealand. J Appl Ecol

Submitted: June 17, 2002; Accepted: September 24, 2002 Proofs received from author(s): December 18, 2002 